\title{
Analysis of Immunoexpression of Estrogen Receptor Beta and Extracellular Matrix Metalloproteinase Inducer (EMMPRIN) on Testicular Seminomas Nonrecurrence and Recurrence
}

\author{
Antonius J. Ridwan, Sri Suryanti, Abdul H. Hassan, Bethy S. Hernowo \\ Department of Pathology Anatomy \\ Faculty of Medicine Padjadjaran University/Hasan Sadikin Hospital Bandung \\ Jl. Pasteur No. 38 Bandung 40161 Indonesia \\ Email : antonius_ridwan@hotmail.com
}

\begin{abstract}
The most common malignancy of testis is seminoma with prognosis that is not always good because of high recurrence rate and death cases. Extracellular matrix metalloproteinase inducer (EMMPRIN) is a glycoprotein adhesion molecules which plays a role in tumor cell invasion and metastasis as evidenced by immunohistochemistry method in several types of tumor cells and tissue that shows the correlation to the clinical progessivity. This study was conducted by observational descriptive analytics with each seven cases of seminoma nonrecurrences and recurrences diagnosed histopathologically from Dr.Hasan Sadikin Hospital, Advent Hospital and St.Borromeus Hospital in Bandung. This study shows that immunoexpression of estrogen receptor beta is not higher in testicular seminoma recurrence compared with nonreccurence. There was no higher imunoexpression of EMMPRIN receptor on testicular seminoma recurrence compared with nonrecurrence; besides, there was no relationship between immunoexspression of estrogen receptor beta and EMMPRIN in testicular seminoma nonrecurrence and recurrence. In conclusion, immunoexpression estrogen receptor beta expressed in all testicular seminoma, so that the patient could be given an alternative therapy and immunoexspression EMMPRIN, cannot be used to predict a recurrence in patients with seminoma who has received complete therapy.
\end{abstract}

Keywords: EMMPRIN, Estrogen Receptor Beta, Seminoma Testis nonrecurrence and recurrence 


\title{
Analisis Imunoekspresi Reseptor Estrogen Beta dan Extracellular Matrix Metalloproteinase Inducer (EMMPRIN) pada Seminoma Testis Nonrekurensi dan Rekurensi
}

\author{
Antonius J. Ridwan, Sri Suryanti, Abdul H. Hassan, Bethy S. Hernowo \\ Departemen Patologi Anatomi \\ Fakultas Kedokteran Unpad/RS Hasan Sadikin Bandung \\ Jl. Pasteur No. 38 Bandung 40161 Indonesia \\ Email : antonius_ridwan@hotmail.com
}

\begin{abstract}
Abstrak
Keganasan testis yang paling umum adalah seminoma dengan prognosis tidak selalu baik karena ditemukan angka rekurensi yang tinggi dan kasus kematian. Hormon estrogen merupakan regulator proliferasi sel dan apoptosis yang diperantarai oleh reseptor estrogen beta sehingga dapat terlibat dalam proses karsinogenesis. Extracellular Matrix Metalloproteinase Inducer (EMMPRIN) adalah molekul adhesi glikoprotein berperan dalam invasi sel tumor dan metastasis yang dibuktikan secara imunohistokimia di beberapa jenis sel tumor dan jaringan sekitarnya serta secara klinis berkorelasi dengan progesivitas. Penelitian ini dilakukan dengan analitik deskriptif observasional terhadap masing-masing tujuh kasus seminoma nonrekurensi dan rekurensi yang didiagnosis secara histopatologis dari arsip RSUP Dr.Hasan Sadikin, RS Advent, dan RS Santo Borromeus Bandung. Hasil penelitian menunjukkan tidak terdapat imunoekspresi reseptor estrogen beta pada seminoma testis rekurensi yang lebih tinggi daripada imunoekspresi reseptor estrogen beta pada seminoma nonrekurensi; tidak terdapat imunoekspresi EMMPRIN pada seminoma testis rekurensi yang lebih tinggi daripada imunoekspresi EMMPRIN pada seminoma nonrekurensi; tidak terdapat hubungan antara imunoekspresi reseptor estrogen beta dan EMMPRIN pada seminoma testis nonrekurensi dan rekurensi. Sebagai simpulan, imunoekspresi reseptor estrogen beta terekspresi pada semua seminoma testis, sehingga pasien dapat diberikan alternatif terapi sedangkan imunoekspresi EMMPRIN tidak dapat digunakan untuk memprediksi seminoma rekurensi pada pasien yang telah mendapat terapi lengkap.
\end{abstract}

Kata kunci: EMMPRIN, Estrogen Reseptor Beta, Seminoma Testis Nonrekurensi dan rekurensi 


\section{Research Article}

\section{Pendahuluan}

Seminoma testis adalah tumor sel germinal (GCT-Germ Cell Tumor) pada testis yang paling banyak ditemukan, yaitu 50\% dari seluruh kasus GCT. Seminoma berasal dari epitel germinal yang terdapat pada tubulus seminiferus testis matur. Sebanyak $95 \%$ tumor testis adalah GCT yang merupakan keganasan yang paling umum dengan usia penderitanya antara usia 15-35 tahun. Tumor testis biasanya unilateral, 3\% dapat terjadi secara bilateral. ${ }^{1,2}$ GCT secara mikroskopik terdiri dari satu unsur dominan atau campuran beberapa unsur sel, dibagi menjadi dua yaitu seminoma dan non seminoma / Non Seminoma Germ Cell Tumor (NSGCT) yang terdiri dari embrional cell carcinoma, yolk sac tumor, dan teratoma. Seminoma dan NSGCT dapat dibedakan dari gambaran klinis dan pemeriksaan histopatologi, yang digunakan untuk menentukan terapi dan prognosis. ${ }^{3,4}$

Menurut data rekam medis di Rumah Sakit Dr. Hasan Sadikin Bandung ditemukan 44 kasus seminoma testis sejak tahun 2008 sampai dengan tahun 2011, sedangkan sebanyak 19 pasien penderita seminoma testis ditemukan di Rumah Sakit Kanker Dharmais Jakarta sejak tahun 2000 sampai dengan tahun 2004. ${ }^{5}$ Menurut penelitian tahun 2010 di Amerika Serikat, dari 8480 kasus tumor seminoma testis ditemukan 350 kematian yang merupakan $1 \%$ dari total tumor tetis. ${ }^{6}$ Di Swiss, khususnya di Vaud Kanton, angka kejadian tumor testis merupakan salah satu yang tertinggi di dunia dan insiden tersebut sampai saat ini masih meningkat. ${ }^{7}$

Menurut National Comphrensive Cancer Network (NCCN) Guidelines Testicular Cancer 2013, prognosis seminoma secara umum baik dengan menggunakan berbagai pilihan terapi, yaitu dengan orchiectomy dilanjutkan radioterapi ataupun kemoterapi, namun terdapat beberapa kasus seminoma yang rekurensi atau bermetastasis setelah beberapa tahun. Seminoma rekurensi adalah semua pasien yang didiagnosis secara histopatologis sebagai seminoma testis unilateral dengan terapi adekuat setelah 2 tahun dan secara klinis dengan pemeriksaan rontgen thorax, CT Scan dan pemeriksaan laboratorium (AFP, beta-HCG dan LDH) ditemukan rekurensi atau metastasis. ${ }^{8}$

Menurut Dr. Mortensen dalam Annual Meeting of the American Society of Clinical Oncology 2013, penderita seminoma testis rekurensi di China ditemukan 1 dari 500 orang tiap tahunnya. Sebanyak 75 - 80\% pasien seminoma tidak bermetastasis (stage I), 20\% bermetastasis ke KGB retroperitoneal, mediastinum, supraklavikula, dan kurang dari 5\% bermetastasis ke organ lain. Pada penelitian lanjut, sebanyak 3-20\% pasien seminoma stage I akan rekurensi atau bermetastasis setelah dilakukan radioterapi atau kemoterapi ajuvan. ${ }^{9}$ Pada beberapa data penelitian di AS (1997-2012) ditemukan rekurensi seminoma sebanyak 19\% setelah 1 tahun, $20 \%$ setelah 2 tahun. 


\section{Research Article}

Penderita seminoma testis yang rekurensi mempunyai prognosis yang lebih buruk dibandingkan dengan penderita seminoma nonrekurensi sehingga pada seminoma rekurensi perlu dilakukan operasi ulang dilanjutkan radioterapi dan kemoterapi ajuvan. ${ }^{8}$ Beberapa penelitian melaporkan adanya kasus kematian sebanyak $<1 \%$ pada seminoma yang rekurensi. ${ }^{10}$ Lokasi tersering (97\%) metastasis pada seminoma testis yaitu daerah retroperitonium dan KGB iliaka. $^{11}$

Faktor risiko dari tumor sel germinal termasuk seminoma sampai saat ini masih kurang dipahami, meskipun beberapa penelitian menyatakan bahwa diduga faktor lingkungan atau genetik merupakan penyebab utama tumor ini. Faktor lain yang diduga berpengaruh yaitu paparan hormon berlebih (khususnya estrogen) selama kehamilan (in utero). ${ }^{12}$ Pada usia dewasa khususnya penderita gynecomastia, penderita dengan pengobatan tumor prostat dengan estrogen, pekerja yang terpapar dengan estrogen (organochlorine), merupakan faktor risiko terjadinya tumor testis. ${ }^{13,14}$

Hormon estrogen tidak lagi dianggap hanya penting bagi wanita, tetapi penting pula bagi kaum pria. Estrogen adalah regulator penting untuk proliferasi sel jaringan reproduksi dan ekstra-reproduksi pada pria dan wanita. ${ }^{15}$ Pada tubuh manusia, estrogen diproduksi dalam bentuk 17ß-estradiol. ${ }^{16,}{ }^{17}$ Pada perkembangan testis, estrogen mempunyai peran aktif dalam pertumbuhan sel sertoli dan sel germinal. ${ }^{18}$ Menurut beberapa penelitian dibuktikan bahwa cytochrome P450 aromatase berfungsi mengubah hormon androgen menjadi hormon estrogen pada manusia. ${ }^{4,19}$ Pada seminoma testis yang rekurensi terdapat peningkatan kadar estrogen yang dihasilkan oleh sel tumor akibat produksi dari sel leydig dan sel sertoli yang meningkat sehingga jumlah reseptor estrogen beta yang mengikat hormon tesebut juga meningkat yang dapat mengakibatkan kerusakan DNA. Patogenesis seminoma rekurensi sampai saat ini belum diketahui dengan pasti. Beberapa ahli meneliti pada seminoma testis yang rekuren, hormon estrogen bentuk $17 \quad \beta$-ethinylestradiol membentuk formasi 7,8-dihydro-8-oxo-2dexoyguanosine, sebagai akibat kerusakan DNA sehingga menghambat ER antagonist. ${ }^{20}$

Reseptor estrogen beta dapat ditemukan dalam testis, duktus eferen dan epididimis, namun, reseptor estrogen alfa dilaporkan tidak ditemukan dalam testis manusia. Dalam testis normal, reseptor estrogen beta dikenal sebagai mediator aksi estrogen fisiologis, jumlah reseptor estrogen beta meningkat terutama pada seminoma dengan rekurensi. ${ }^{14,19,21,22}$

Mekanisme terjadinya seminoma rekurensi yaitu adanya gangguan pada inhibin inhibitor yang berfungsi menghambat produksi hormon estrogen yang menyebabkan sel leydig dan sel sertoli mensekresi hormon estrogen secara berlebihan dan kemudian diikat oleh estrogen reseptor beta. Gangguan pada inhibin inhibitor pada seminoma testis disebabkan adanya kerusakan dan mutasi DNA sehingga dapat mengubah ekspresi gen. ${ }^{23}$ Pada penelitian ini akan 


\section{Research Article}

digunakan marker reseptor estrogen beta pada seminoma testis nonrekurensi dan rekurensi yang mana dapat dibedakan tingkat imunoekspresi reseptor estrogen beta akan lebih tinggi pada seminoma testis rekurensi dibandingkan dengan imunoekspresi seminoma testis nonrekurensi.

Extracellular matrix metalloproteinase inducer (EMMPRIN) adalah molekul adhesi glikoprotein yang merupakan immunoglobulin yang berasal dari purifikasi permukaan LX-1 sel epitel tumor paru. ${ }^{24,25}$ EMMPRIN berfungsi menstimulasi fibroblast dan produksi sel endotel MMP pada gen dengan lokasi kromosom 19p13.3. ${ }^{26}$ Enzim yang berkaitan dengan sintesis dan stimulasi EMMPRIN yaitu MMP-1, MMP-2, dan MMP-9. Pengaktifan sintesis MMP-1 dimediasi oleh aktifasi mitogen protein kinase p38. ${ }^{27}$ EMMPRIN mempunyai kemampuan mengikat MMP-1 di permukaan sel tumor. ${ }^{28-31}$

Peran EMMPRIN dalam invasi sel tumor dan metastasis dibuktikan secara imunohistokimia di beberapa jenis keganasan, seperti karsinoma sel skuamosa pada esofagus, astrositoma dan melanoma. Selain itu, ekspresi EMMPRIN telah dilaporkan secara klinis berkorelasi dengan prognosis pasien pada karsinoma payudara dan karsinoma ovarium. ${ }^{32}$ Pada satu penelitian dibuktikan bahwa tingkat ekspresi dari EMMPRIN berkorelasi dengan stadium klinis dan progresi dari beberapa karsinoma pada sistem kemih, seperti ginjal, prostat, dan karsinoma kandung kemih. ${ }^{33}$

Pada penelitian ini digunakan marker EMMPRIN untuk memprediksi terjadinya seminoma rekurensi. Secara fisiologis, testis dewasa terdapat matrix metalloproteinase (MMPs) dan Tissue Inhibitor of MMPs (TIMPs) yang dihasilkan oleh sel sertoli dan sel leydig. Pada seminoma testis rekurensi terjadi ketidakseimbangan matrix metalloproteinases (MMPs) dan Tissue Inhibitor of MMPs (TIMPs) sehingga terjadi kerusakan dari matrik ekstraselular, sehingga sel-sel tumor menginvasi ke jaringan sekitar dan menyebabkan metastasis dan angiogenesis. ${ }^{28}$ Efek EMMPRIN pada seminoma nonrekurensi dan rekurensi sampai saat ini belum dilaporkan, sehingga pada penelitian ini digunakan EMMPRIN dan diharapkan imunoekspresi EMMPRIN lebih tinggi pada seminoma rekurensi dibandingkan dengan imunoekspresi seminoma nonrekurensi.

Sampai saat ini belum ada laporan penelitian khususnya mengenai efek imunoekspresi Reseptor Estrogen Beta dan EMMPRIN pada seminoma nonrekurensi dan rekurensi. Tujuan penelitian ini diharapkan memberikan informasi ilmiah tentang imunoekspresi reseptor estrogen beta dan EMMPRIN dapat digunakan sebagai salah satu parameter memprediksi kemungkinan rekurensi pada seminoma testis dan diharapkan dapat dipakai sebagai acuan dalam tatalaksana seminoma testis sehingga pada penderita seminoma testis dapat diberikan obat anti estrogen sebagai terapi ajuvan dan mencegah terjadinya rekurensi. 


\section{Research Article}

\section{Metode}

Bahan penelitian adalah blok parafin dari pasien yang didiagnosis secara histopatologis sebagai seminoma testis sejak 1 Januari 2008 sampai 30 Juni 2013 dari arsip Laboratorium Patologi Anatomi Fakultas Kedokteran Universitas Padjadjaran/ Rumah Sakit Dr.Hasan Sadikin Bandung dan sejak 1 Januari 2000 sampai 30 Juni 2013 di laboratorium Rumah Sakit Advent serta laboratorium Rumah Sakit Santo Borromeus Bandung. Masing-masing kelompok seminoma nonrekurensi dan rekurensi dengan sampel masing-masing sebanyak 7 orang.

Prosedur penelitian yaitu pengumpulan data kasus seminoma testis yang telah diperiksa secara histopatologis di Laboratorium Patologi Anatomi RS Dr. Hasan Sadikin, RS Advent, dan RS Borromeus Bandung kemudian dilakukan pengumpulan blok parafin dari kasus seminoma testis dan pencatatan data rekam medis. Blok parafin dari penderita seminoma testis dibuatkan sediaan histopatologis dan diwarnai dengan pulasan imunohistokimia Reseptor Estrogen Beta dan EMMPRIN. Semua sediaan diperiksa di bawah mikroskop cahaya merk Olympus CX 21 untuk dilihat tingkat imunoekspresi Reseptor Estrogen Beta dan EMMPRIN menggunakan pembesaran 400x, dilihat di lima lapang pandang dan dihitung tiap 100 sel. Imunoekspresi Reseptor Estrogen Beta dihitung berdasarkan sel tumor berwarna kecoklatan pada inti sel tumor, sedangkan imunoekspresi EMMPRIN dihitung berdasarkan sel tumor berwarna kecoklatan pada sitoplasma sel tumor. Setelah diskoring, kemudian dianalisis dengan menggunakan chi-square.

\section{Hasil dan Diskusi}

Karakteristik subjek penelitian adalah sebagai berikut: usia $\leq 50$ tahun sebanyak 8 kasus $(57,14 \%)$ dan usia $>50$ tahun sebanyak 6 kasus $(42,86 \%)$; usia rerata adalah 49,4 tahun, untuk kelompok seminoma nonrekurensi adalah 55,3 tahun dan untuk kelompok seminoma rekurensi adalah 43,6 tahun. Berdasarkan jenis histopatologi, seminoma tipe klasik sebanyak 9 kasus $(64,28 \%)$ dan seminoma non klasik sebanyak 5 kasus $(35,72 \%)$. Pada seminoma testis rekurensi, sebanyak 4 kasus (57,14\%) metastasis atau rekurensi ke KGB inguinal dan sebanyak 3 kasus $(42,86 \%)$ bermetastasis ke mediastinum, testis kontralateral, dan intraabdomen (tabel 1). 


\section{Research Article}

Tabel 1 Data Karakteristik Kasus Seminoma Testis

\begin{tabular}{lll}
\hline Variabel & $\mathrm{N}$ & $\%$ \\
\hline - Usia (tahun) & & \\
$\quad \leq 50$ tahun & 8 & 57,14 \\
$>50$ tahun & 6 & 42,86 \\
- Rerata Usia (tahun) & 49,4 & \\
$\quad$ Seminoma nonrekurensi & 55.3 & \\
$\quad$ Seminoma rekurensi & 43,6 & \\
- Respon Terapi & & 50 \\
$\quad$ Seminoma nonrekurensi & 7 & 50 \\
$\quad$ Seminoma rekurensi & 7 & 64,28 \\
Jenis Histopatologi & & 35,72 \\
$\quad$ Seminoma Klasik & 9 & 57,14 \\
$\quad$ Seminoma NonKlasik & 5 & 42,86 \\
$\quad$ Rekurensi / Metastasis & & 100 \\
$\quad$ KGB & 4 & \\
$\quad$ Lain-lain & 3 & \\
Total Subyek Penelitian & 14 & \\
\hline
\end{tabular}

Imunoekspresi reseptor estrogen beta (ER $\beta)$ pada penelitian ini dinilai dari terwarnainya inti menjadi berwarna coklat setelah diberikan antibodi primernya. Hasil pulasan imunohistokimia reseptor estrogen beta pada penelitian ini memberikan imunoekspresi reseptor estrogen beta sebagai berikut; 7 orang yang termasuk kelompok nonrekurensi, 1 orang memiliki skor rendah, masing-masing 3 orang memiliki skor sedang dan tinggi; dan dari 7 orang yang termasuk kelompok rekurensi, 5 orang memiliki skor sedang dan masing-masing 1 orang memiliki skor rendah dan tinggi (tabel 2).

Tabel 2 Hasil Imunoekspresi Reseptor Estrogen Beta pada Seminoma

\begin{tabular}{|c|c|c|c|c|c|}
\hline \multirow{2}{*}{ ERB } & & \multicolumn{2}{|l|}{ Group } & \multirow{2}{*}{ Total } & \multirow{3}{*}{$\chi_{\text {hitung }}^{2}=1,500$} \\
\hline & & NonRekurensi & Rekurensi & & \\
\hline \multirow{2}{*}{ Negatif/Rendah } & $\mathrm{F}$ & 1 & 1 & 2 & \\
\hline & $\%$ & 14,3 & 14,3 & 14,3 & \multirow{2}{*}{$\mathrm{df}=2$} \\
\hline \multirow{2}{*}{ Sedang } & $\mathrm{f}$ & 3 & 5 & 8 & \\
\hline & $\%$ & 42,9 & 71,4 & 57,1 & \multirow{3}{*}{$\chi_{\text {tabel }}^{2}=5,991$} \\
\hline \multirow{2}{*}{ Tinggi } & $\mathrm{f}$ & 3 & 1 & 4 & \\
\hline & $\%$ & 42,9 & 14,3 & 28,6 & \\
\hline \multirow{2}{*}{ Total } & $\mathrm{F}$ & 7 & 7 & 14 & \multirow{2}{*}{$\operatorname{Sig}=0,472$} \\
\hline & $\%$ & 100,0 & 100,0 & 100,0 & \\
\hline
\end{tabular}

Imunoekspresi EMMPRIN pada penelitian ini dinilai dari terwarnainya sitoplasma menjadi berwarna coklat setelah diberikan antibodi primernya. Hasil pulasan imunohistokimia 


\section{Research Article}

EMMPRIN pada penelitian ini yaitu dari 7 orang yang termasuk kelompok nonrekurensi, 1 orang memiliki skor rendah, 6 orang memiliki skor sedang; dari 7 orang yang termasuk kelompok rekurensi, masing-masing 2 orang memiliki skor rendah dan sedang; dan 3 orang memiliki skor tinggi (tabel 3).

Tabel 3 Hasil Imunoekspresi EMMPRIN pada Seminoma

\begin{tabular}{|c|c|c|c|c|c|}
\hline \multirow{2}{*}{ EMMPRIN } & & \multicolumn{2}{|l|}{ Group } & \multirow{2}{*}{ Total } & \multirow{3}{*}{$\chi_{\text {hitung }}^{2}=5,333$} \\
\hline & & NonRekurensi & Rekurensi & & \\
\hline \multirow{2}{*}{ Negatif/Rendah } & $\mathrm{f}$ & 1 & 2 & 3 & \\
\hline & $\%$ & 14,3 & 28,6 & 21,4 & \multirow{2}{*}{$\mathrm{df}=2$} \\
\hline \multirow{2}{*}{ Sedang } & $\mathrm{f}$ & 6 & 2 & 8 & \\
\hline & $\%$ & 85,7 & 28,6 & 57,1 & \multirow{3}{*}{$\chi_{\text {tabel }}^{2}=5,991$} \\
\hline \multirow{2}{*}{ Tinggi } & $\mathrm{f}$ & 0 & 3 & 3 & \\
\hline & $\%$ & 0,0 & 42,9 & 21,4 & \\
\hline \multirow[t]{2}{*}{ Total } & $\mathrm{f}$ & 7 & 7 & 14 & \multirow{2}{*}{$\operatorname{Sig}=0,069$} \\
\hline & $\%$ & 100,0 & 100,0 & 100,0 & \\
\hline
\end{tabular}

Pada perhitungan statistik menggunakan uji Chi-Square untuk menilai hubungan antara imunoekspresi reseptor estrogen beta dengan EMMPRIN pada seminoma testis nonrekurensi dan rekurensi dapat dilihat pada tabel 4 dan tabel 5.

Tabel 4 Hubungan Hasil Imunoekspresi ERß dengan EMMPRIN pada Seminoma Rekurensi

\begin{tabular}{|c|c|c|c|c|c|}
\hline \multirow{2}{*}{\multicolumn{2}{|c|}{ Kategori skor }} & \multicolumn{2}{|l|}{ Group } & \multirow{3}{*}{\multicolumn{2}{|c|}{$\begin{array}{l}\text { Total } \\
3\end{array}$}} \\
\hline & & \multirow{2}{*}{$\begin{array}{l}\text { EMMPRIN } \\
2\end{array}$} & \multirow{2}{*}{$\begin{array}{l}\text { ERB } \\
1 \\
\end{array}$} & & \\
\hline \multirow{2}{*}{ Negatif/Rendah } & $\mathrm{f}$ & & & & \\
\hline & $\%$ & 28,6 & 14,3 & 21,4 & \multirow{2}{*}{$\mathrm{df}=2$} \\
\hline \multirow{2}{*}{ Sedang } & f & 2 & 5 & 7 & \\
\hline & $\%$ & 28,6 & 71,4 & 50,0 & \multirow{3}{*}{$\chi_{\text {tabel }}^{2}=5,991$} \\
\hline \multirow{2}{*}{ Tinggi } & $\mathrm{f}$ & 3 & 1 & 4 & \\
\hline & $\%$ & 42,9 & 14,3 & 28,6 & \\
\hline \multirow[t]{2}{*}{ Total } & $\mathrm{f}$ & 7 & 7 & 14 & \multirow{2}{*}{$\mathrm{Sig}=0,270$} \\
\hline & $\%$ & 100,0 & 100,0 & 100,0 & \\
\hline
\end{tabular}

Tabel 5 Hubungan Hasil Imunoekspresi ERß dengan EMMPRIN 


\section{Research Article}

\section{pada Seminoma Non-Rekurensi}

\begin{tabular}{|c|c|c|c|c|c|}
\hline \multirow{2}{*}{ K_skor } & & \multicolumn{2}{|l|}{ Group } & \multirow{2}{*}{ Total } & \multirow{3}{*}{$\chi_{\text {hitung }}^{2}=4,000$} \\
\hline & & EMMPRIN & ERB & & \\
\hline \multirow{2}{*}{ Negatif/Rendah } & $\mathrm{f}$ & 1 & 1 & 2 & \\
\hline & $\%$ & 14,3 & 14,3 & 14,3 & \multirow{2}{*}{$\mathrm{df}=2$} \\
\hline \multirow{2}{*}{ Sedang } & $\mathrm{f}$ & 6 & 3 & 9 & \\
\hline & $\%$ & 85,7 & 42,9 & 64,3 & \multirow{3}{*}{$\chi_{\text {tabel }}^{2}=5,991$} \\
\hline \multirow{2}{*}{ Tinggi } & $\mathrm{f}$ & 0 & 3 & 3 & \\
\hline & $\%$ & 0,0 & 42,9 & 21,4 & \\
\hline \multirow[t]{2}{*}{ Total } & $\mathrm{f}$ & 7 & 7 & 14 & \multirow{2}{*}{$\operatorname{Sig}=0,135$} \\
\hline & $\%$ & 100,0 & 100,0 & 100,0 & \\
\hline
\end{tabular}
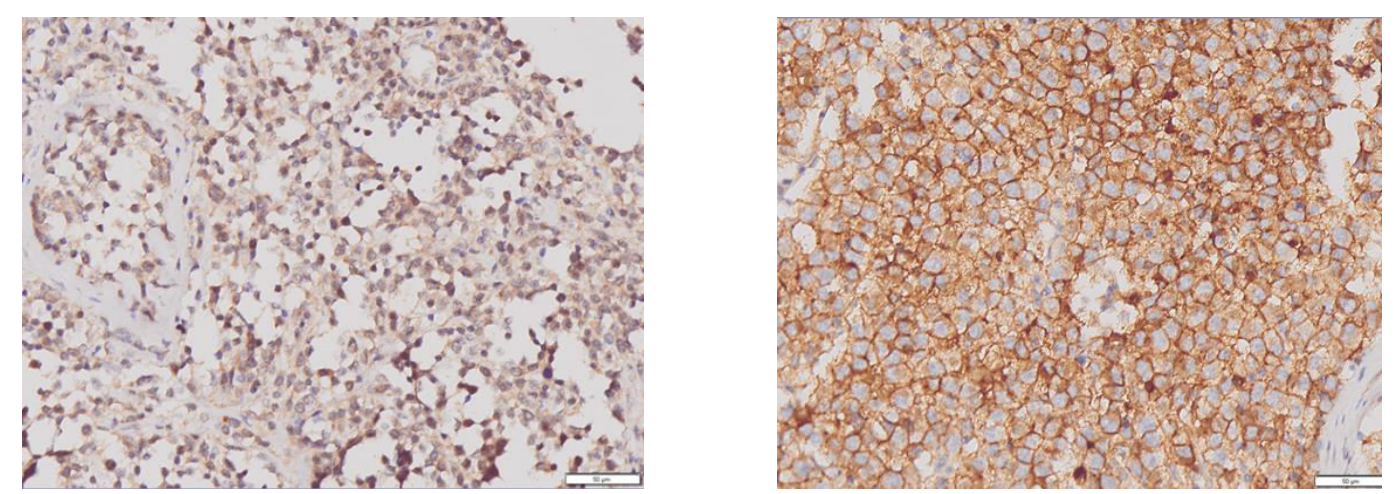

\section{Gambar 1 Imunoekspresi ERß Skor Tinggi (200x) dan Imunoekspresi EMMPRIN skor Tinggi (200x)}

Estrogen reseptor beta mungkin merupakan faktor prediktif yang paling utama yang diperiksa pada seminoma testis. Hal ini mempunyai implikasi terapeutik yang signifikan. ${ }^{34}$ Secara umum konsentrasi ER lebih rendah pada testis normal daripada seminoma testis. ${ }^{22}$

Penelitian ini menggunakan marker reseptor estrogen beta pada seminoma testis nonrekurensi dan rekurensi dengan hasil semua kasus memberikan hasil positif yaitu positif lemah sampai dengan positif kuat (skor 5 - skor 8). Tidak ada yang memberikan hasil negatif (skor 0). Penelitian ini menunjukkan bahwa pada seminoma testis terdapat peningkatan hormon estrogen sebagai etiologi terjadinya keganasan pada testis. Penelitian yang dilakukan oleh Vittoria dkk (2009) memberikan hasil dan kesimpulan yang sama yaitu reseptor estrogen beta memberikan hasil positif pada tumor sel germinal khususnya seminoma. ${ }^{19}$ Penelitian Vernon dkk (2013) estrogen dapat memengaruhi pertumbuhan dan progresifitas sel germinal untuk menjadi suatu keganasan melalui interaksi dengan reseptor estrogen beta. ${ }^{14}$ 


\section{Research Article}

Pada penelitian ini sampel kasus seminoma dipisahkan antara seminoma nonrekurensi dan rekurensi, masing-masing 7 kasus dilakukan pewarnaan reseptor estrogen beta kemudian dilakukan skoring dan analisis statistik dengan menggunakan chi-square dan didapatkan hasil bahwa tidak terdapat imunoekspresi reseptor estrogen beta pada seminoma testis rekurensi yang lebih tinggi daripada imunoekspresi reseptor estrogen beta pada seminoma nonrekurensi. Dapat disimpulkan bahwa reseptor estrogen beta memberikan hasil positif pada semua seminoma testis nonrekurensi dan rekurensi namun perbedaannya tidak signifikan diantara keduanya. Hal ini disebabkan karena pada seminoma testis terjadi peningkatan hormon estrogen yang diikat oleh reseptor estrogen beta akan tetapi tidak mempengaruhi pembelahan dari inti sel seperti terdapat pada gambar 2 .

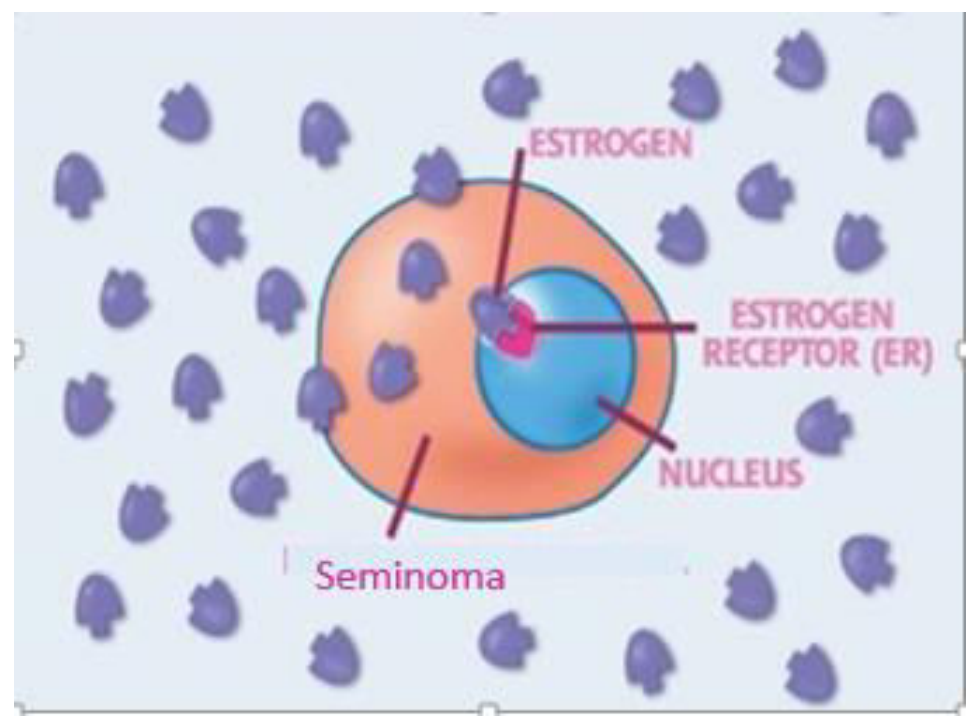

\section{Gambar 2 Ikatan Hormon Estrogen dengan ER pada Seminoma Diunduh dari http://trialx.com/curebyte/2011/06/16.htm h $^{34}$}

Suatu tumor / keganasan menurut Robbins (2010) memberikan prognosis yang baik setelah mendapatkan terapi adekuat, akan tetapi masih ditemukan rekurensi atau metastasis yang semakin meningkat akhir-akhir ini. Berbagai penelitian telah dilakukan untuk menentukan apakah tumor tersebut akan mengalami rekurensi atau tidak rekurensi dengan menggunakan imunohistokimia pada manusia maupun hewan percobaan. Salah satu marker yang digunakan untuk prediksi rekurensi yaitu Extracellular Matrix Metalloproteinase Inducer (EMMPRIN) pada tumor payudara, ovarium, paru dan esofagus. Beberapa penelitian memberikan hasil imunoekspresi EMMPRIN meningkat pada sel-sel tumor yang mempunyai progresifitas tinggi. ${ }^{35}$ 


\section{Research Article}

Pada penelitian ini digunakan marker EMMPRIN pada 14 kasus seminoma nonrekurensi dan seminoma rekurensi kemudian dilakukan skoring (0-2) kemudian digunakan analisis uji chi-square dan hasilnya disimpulkan tidak terdapat imunoekspresi EMMPRIN pada seminoma testis rekurensi yang lebih tinggi daripada imunoekspresi EMMPRIN pada seminoma nonrekurensi. Penjelasan untuk fenoma ini adalah seminoma tesis memproduksi EMMPRIN yang merupakan glikoprotein pada permukaan sel dan distimulasi langsung oleh fibroblast untuk memproduksi MMP sehingga sel tumor tersebut mengalami metastasis. Terdapat peningkatan MMP tersebut selain dipengaruhi oleh peningkatan EMMPRIN, juga disebabkan adanya faktor Environment Compartment yang terdiri dari kolagen, fibroblast, laminin dan fibronektin, sehingga pada kasus ini EMMPRIN bukan merupakan faktor yang beperan langsung terhadap terjadinya metastasis. Proses tersebut dijelaskan pada gambar 3 .

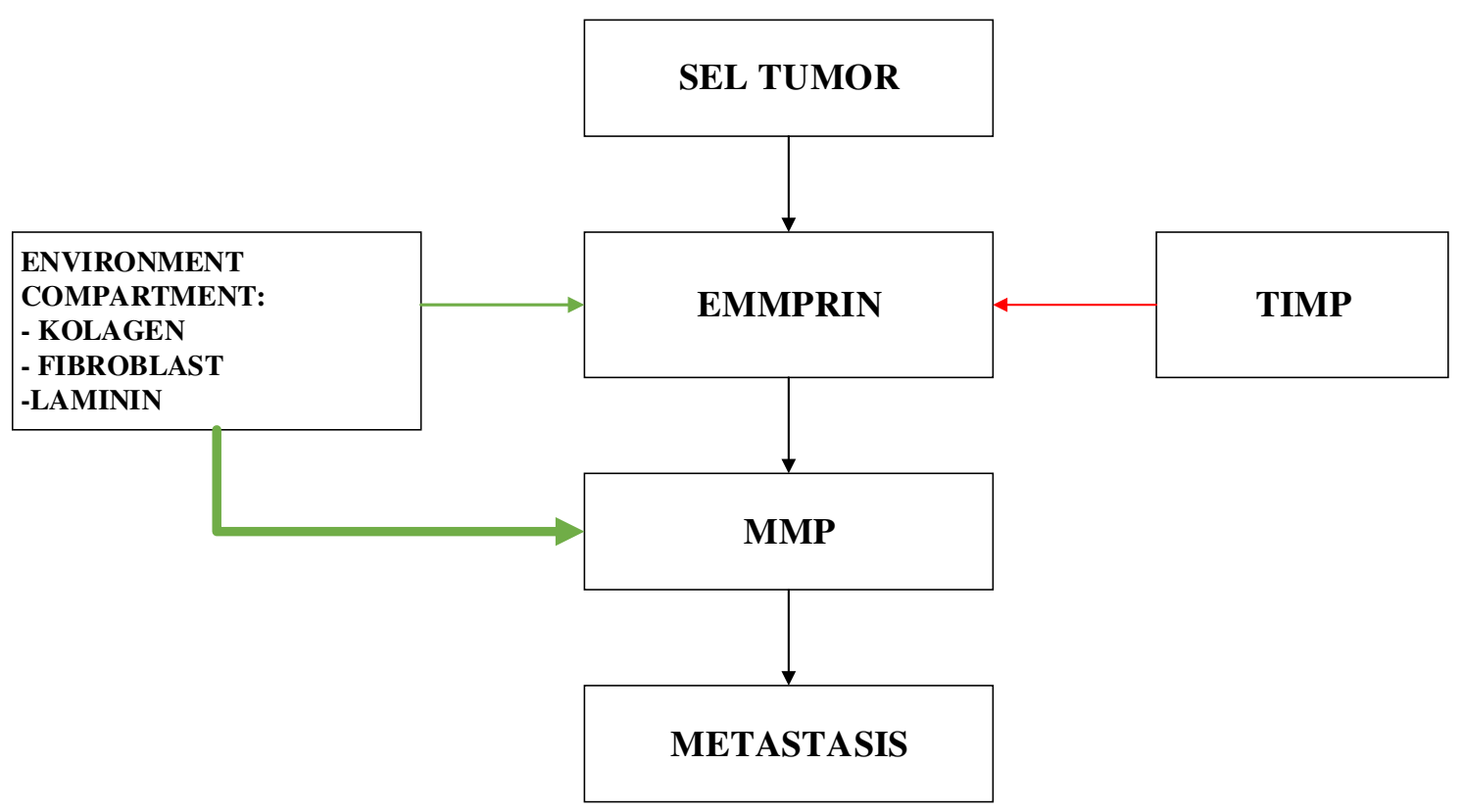

Gambar 3 Mekanisme EMMPRIN dengan Environment Compartment ${ }^{36}$

Pada penelitian ini, dilakukan analisis hubungan antara imunoekspresi reseptor estrogen beta dengan EMMPRIN pada seminoma testis nonrekurensi dan rekurensi dengan menggunakan uji chi-square dengan hasil tidak signifikan yaitu tidak terdapat hubungan antara imunoekspresi reseptor estrogen beta dan EMMPRIN pada seminoma testis nonrekurensi dan rekurensi. Hasil ini sesuai dengan penelitian yang dilakukan oleh L Chen (2010) dengan menggunakan testis pada mencit bahwa tidak ada hubungan antara reseptor estrogen dengan EMMPRIN. Reseptor estrogen beta dan EMMPRIN memberikan hasil yang positif pada tumor 


\section{Research Article}

sel germinal, akan tetapi jika reseptor estrogen tersebut dihilangkan maka tidak mempengaruhi kerja EMMPRIN, demikian juga dengan sebaliknya. ${ }^{37}$

Penelitian ini memberikan hasil yang tidak bermakna sehingga dapat disimpulkan bahwa imunoekspresi Estrogen Reseptor Beta dan EMMPRIN bukan merupakan salah faktor yang berperan sebagai prediksi metastasis atau rekurensi pada tumor. Menurut penelitian Beatrice et al (2008) dan Avix Som et al (2012) terdapat faktor-faktor lain yang mendukung terjadinya metastasis seperti Staging, ukuran tumor, pemeriksaan laboratorium (AFP, beta-HCG dan LDH). Semakin tinggi Staging, ukuran tumor dan kenaikan hasil pemeriksaan AFP, betaHCG dan LDH, maka semakin progresif tumor tersebut untuk bermetastasis. ${ }^{38}$

\section{Simpulan}

Simpulan secara umum pada penelitian ini yaitu tidak terdapat imunoekspresi reseptor estrogen beta pada seminoma testis rekurensi yang lebih tinggi daripada imunoekspresi reseptor estrogen beta pada seminoma nonrekurensi, tidak terdapat imunoekspresi EMMPRIN pada seminoma testis rekurensi yang lebih tinggi daripada imunoekspresi EMMPRIN pada seminoma nonrekurensi; tidak terdapat hubungan antara imunoekspresi reseptor estrogen beta dan EMMPRIN pada seminoma testis nonrekurensi dan rekurensi.

Simpulan secara khusus pada penelitian ini yaitu imunoekspresi reseptor estrogen beta terekspresi pada semua seminoma testis nonrekurensi dan rekurensi; imunoekspresi EMMPRIN tidak dapat digunakan untuk memprediksi seminoma rekurensi pada pasien yang telah mendapat terapi lengkap.

\section{DAFTAR PUSTAKA}

1. Heidenreich A, Weissbach L, Holtl W, Albers P, Kliesch S, Kohrmann KU, et al. Organ Sparing Surgery for Malignant Germ Cell Tumor of The Testis. J Urol. 2001;166(6):2161-5

2. Boujelbene N, Cosinschi A, Boujelbene N, Khanfir K, Bhagwati S, Herrmann E, et al. Pure Seminoma: A Review and Update. Radiat Oncol. 2011;6:90

3. Ulbright, T. M., Young RH. Germ Cell Tumors: Histogenetic Considerations and Intratubular Germ Cell Neoplasia. Dalam: Rosai J, Sobin. LH, editors. Armed Forces Institute of Pathology Atlas of Tumor Pathology, Tumors of the Testis, Adnexa, Spermatic Cord and Scrotum. Washington, DC: Armed Forces Institute of Pathology; 1999. p. 41-180

4. Rago V, Romeo F, Aquila S, Montanaro D, Ando S, Carpino A. Cytochrome P450 Aromatase Expression in Human Seminoma. Reprod Biol Endocrinol: RB\&E. 2005;3:72

5. Andayani YD, Safei S. Pattern of Germ Cell Testicular Carcinoma in Dharmais Cancer Hospital between January 2000-December 2004. Acta medica Indonesiana. 2008; 40(1):11-3

6. Jemal A, Siegel R, Xu J, Ward E. Cancer Statistics, 2010. CA Cancer J Clin. 2010;60(5):277-300

7. Levi F, Te VC, Randimbison L, La Vecchia C. Trends in Testicular Cancer Incidence in Vaud, Switzerland. Eur J Cancer Prev. 2003;12(4):347-9

8. Motzer RJ, Agarwal N, Beard C, Bolger GB, Boston B, Carducci MA, et al. NCCN Clinical Practice Guidelines in Oncology: Testicular Cancer. J Natl Compr Canc Netw. 2013;7(6):672-93

9. Skakkebaek NE, Rajpert-De Meyts E, Jorgensen N, Main KM, Leffers H, Andersson AM, et al. Testicular Cancer Trends As 'Whistle Blowers' of Testicular Developmental Problems In Populations. Int J Androl. 2007;30(4):198-204; discussion -5 


\section{Research Article}

10. Bi XC, Liu JM, He HC, Ye YK, Han ZD, Dai QS, et al. Extracellular Matrix Metalloproteinase Inducer: A Novel Poor Prognostic Marker for Human Seminomas. Clin Transl Oncol. 2012;14(3):190-6

11. Schmoll HJ, Jordan K, Huddart R, Laguna MP, Horwich A, Fizazi K, et al. Testicular Seminoma: ESMO clinical Recommendations for diagnosis, Treatment and Follow-up. Ann Oncol. 2009; 20 Suppl 4:83-8

12. Kinugawa K, Hyodo F, Matsuki T, Jo Y, Furukawa Y, Ueki A, et al. Establishment and Characterization of A New Human Testicular Seminoma Cell Line, JKT-1. Int J Urol. 1998;5(3):282-7

13. Idrees M, Saxena R, Cheng L, Ulbright TM, Badve S. Podoplanin, A Novel Marker for Seminoma: A Comparison Study Evaluating Immunohistochemical Expression of Podoplanin and OCT3/4. Ann Diagn Pathol. $2010 ; 14(5): 331-6$

14. Pais V, Leav I, Lau KM, Jiang Z, Ho SM. Estrogen Receptor-Beta Expression in Human Testicular Germ Cell Tumors. Clin Cancer Res. 2003;9(12):4475-82

15. Roger C, Lambard S, Bouskine A, Mograbi B, Chevallier D, Nebout M, et al. Estrogen-induced Growth Inhibition of Human Seminoma Cells Expressing Estrogen Receptor Beta and Aromatase. J Mol Endocrinol. 2005;35(1):191-9

16. Carreau S, Bourguiba S, Lambard S, Galeraud-Denis I, Genissel C, Levallet J. Reproductive System: Aromatase and Estrogens. Mol Cell Endocrinol. 2002;193(1-2):137-43

17. Strohsnitter WC, Noller KL, Hoover RN, Robboy SJ, Palmer JR, Titus-Ernstoff L, et al. Cancer Risk in Men Exposed In Utero To Diethylstilbestrol. J Natl Cancer Intl. 2001;93(7):545-51

18. Carreau S, Bouraima-Lelong H, Delalande C. Estrogens: New Players in Spermatogenesis. Reprod Biol. 2011 ;11(3):174-93

19. Rago V, Romeo F, Giordano F, Ferraro A, Ando S, Carpino A. Identification of ERbeta1 and ERbeta2 in Human Seminoma, in Embryonal Carcinoma and In Their Adjacent Intratubular Germ Cell Neoplasia. Reprod Biol Endocrinol: RB\&E. 2009;7:56

20. Fujimura T, Takahashi S, Urano T, Xiaoqiang L, Ogushi T, Muramatsu M, et al. Estrogen Receptor-Binding Fragment-Associated Gene 9 Expression and Its Clinical Significance in Human Testicular Cancer. Int J Urol : official J of the Japanese Uro Assoc. 2009;16(3):329-32

21. Nilsson S, Makela S, Treuter E, Tujague M, Thomsen J, Andersson G, et al. Mechanisms of Estrogen Action. Physiol Rev. 2001;81(4):1535-65

22. Makinen S, Makela S, Weihua Z, Warner M, Rosenlund B, Salmi S, et al. Localization of Oestrogen Receptors Alpha and Beta In Human Testis. Mol Hum Reprod. 2001;7(6):497-503

23. Lazari MF, Lucas TF, Yasuhara F, Gomes GR, Siu ER, Royer C, et al. Estrogen Receptors and Function In The Male Reproductive System. Arq Bras Endocrinol Metabol. 2009;53(8):923-33

24. Zucker S, Hymowitz M, Rollo EE, Mann R, Conner CE, Cao J, et al. Tumorigenic Potential of Extracellular Matrix Metalloproteinase Inducer. Am J Pathol. 2001;158(6):1921-8

25. Biswas C, Zhang Y, DeCastro R, Guo H, Nakamura T, Kataoka H, et al. The Human Tumor Cell-Derived Collagenase Stimulatory Factor (renamed EMMPRIN) is A Member of The Immunoglobulin Superfamily. Cancer Res. 1995;55(2):434-9

26. Guo H, Majmudar G, Jensen TC, Biswas C, Toole BP, Gordon MK. Characterization of The Gene for Human EMMPRIN, A Tumor Cell Surface Inducer of Matrix Metalloproteinases. Gene. 1998;220(1-2):99-108

27. Sun J, Hemler ME. Regulation of MMP-1 and MMP-2 Production Through CD147/extracellular Matrix Metalloproteinase Inducer Interactions. Cancer Res. 2001;61(5):2276-81

28. Tang Y, Kesavan P, Nakada MT, Yan L. Tumor-stroma Interaction: Positive Feedback Regulation of Extracellular Matrix Metalloproteinase Inducer (EMMPRIN) Expression and Matrix MetalloproteinaseDependent Generation of Soluble EMMPRIN. Mol Cancer Res: MCR. 2004;2(2):73-80

29. Sengupta N, MacDonald TT. The Role of Matrix Metalloproteinases In Stromal/Epithelial Interactions in The Gut. Physiology. 2007;22:401-9

30. Sidhu SS, Mengistab AT, Tauscher AN, LaVail J, Basbaum C. The Microvesicle As A Vehicle for EMMPRIN in Tumor-Stromal Interactions. Oncogene. 2004;23(4):956-63

31. Agrawal SM, Yong VW. The Many Faces of EMMPRIN - Roles in Neuroinflammation. Biochim biophys acta. 2011;1812(2):213-9

32. Mi Z, Oliver T, Guo H, Gao C, Kuo PC. Thrombin-cleaved COOH(-) Terminal Osteopontin Peptide Binds with Cyclophilin C to CD147 in Murine Breast Cancer Cells. Cancer Res. 2007;67(9):4088-97

33. Tsai WC, Sheu LF, Nieh S, Yu CP, Sun GH, Lin YF, et al. Association of EMMPRIN and Fascin Expression in Renal Cell Carcinoma: Correlation With Clinicopathological Parameters. World J Uro. 2007;25(1):73-80

34. Estrogen Receptor 2010. Diunduh 10 Februari 2014 dari: http://trialx.com/curebyte/2011/06/16.html.

35. Zucker S, Hymowitz M, Rollo EE, Mann R, Conner CE, Cao J, et al. Tumorigenic Potential of Extracellular Matrix Metalloproteinase Inducer. The American journal of pathology. 2011;158(6):1921-8

36. Sun J, Hemler ME. Regulation of MMP-1 and MMP-2 Production Through CD147/Extracellular Matrix Metalloproteinase Inducer Interactions. Cancer research. 2010;61(5):2276-81

37. Chen L, Bi J, Nakai M, Bunick D, Couse JF, Korach KS, et al. Expression of Basigin In Reproductive Tissues of Estrogen Receptor- $\{$ alpha $\}$ or - $\{$ beta\} Null Mice. Reproduction. 2010;139(6):1057-66

38. Som A, Zhu R, Guo CC, Efstathiou E, Xiao L, Pisters LL, et al. Recurrent Seminomas: Clinical Features and Biologic Implications. Urologic oncology. 2012;30(4):494-501 